\title{
INTERDISCIPLINARY STUDY OF RENEWABLE ENERGY RESOURCES IN INDIA
}

\author{
S.Z. Fakir ${ }^{1}$, S.K. Auti ${ }^{1,}$ N.V. Misal ${ }^{2}$ and S.A. Najan ${ }^{3}$ \\ 1. Dept. of. Geography A.C.S, College, Sonai Tal. Newasa, Dist. Ahemednagar \\ 2. Dept. of . Marathi A.C.S College, Sonai, Tal. Newasa, Dist. Ahemednagar \\ 3. Dept. of. Chemistry A.C.S, College, Sonai, Tal. Newasa, Dist. Ahemednagar \\ E.mail:- shoukatfakir@gmail.com
}

Communicated: 25.02 .21

Revision :26.03.21 \& 17.04.2021

Accepted: 13.05 .2021

Published: 30.05.2021

\begin{abstract}
:
Energy is most necessary for economic and social development for every nation. Man had found out number of sources of energy resources form the past history. Convectional energy resources are the coal, petroleum and hydro- electricity. This energy resource has limitation. As per global demand of the energy, there are new non- conventional energy resources as the solar energy, wind energy, bio-gases etc. These non- convectional energy resources have efficiency than the conventional energy resource. India had made his new energy policy on the basis of non- conventional energy resource. Solar energy and wind energy has more potential capacity inthis energy resource in India. India is one of the large productions of energy from renewable sources. India has installed electricity generation capacity form non-conventional energy is $39 \%$. These non-convectional energy resources are the renewable type energy resources. It is eco-friendly energy resources. Due to it more capacity in production of electricity, cycle type utilization and low environment problems. It had lot of scope in the energy sector.
\end{abstract}

\section{INTRODUCTION:}

Energy is most important element of human activity. With the help of this energy sources, man can be made number of activities asagriculture, transportation and industrialization. This energy is applied in the domestic activity. National economic growth is depending on generation of the electricity; today total global need of electricity is $30,000 \mathrm{GWh}$. It had predicted that up to the 2050 this demand of electricity will be up to 50,000 GWh. Government of India is trying to discover number of sources for the generation of the electricity. These energy sources can be classified as Renewable energy sources and non-renewable energy sources. Energy which can be use again and again is known as the renewable energy sources. Non- renewable sources are not use again and again; these are ending by one time use. There are two type of sources for this energy resources as the renewable and non-renewable energy sources. Renewable energy

sources can be use again and again. Nonrenewable energy sources are ending by one time uses, we cannot be use it next time. After the generation of electricity, it has not emitted carbon material in your environment. After 1990 there is global problem as the global warming.

This global warming had effecting on the global climatic changes. In case of the energy sector, it had the shortages of electricity for the global level. Today more than $30 \%$ population of the 
world are in darken condition, that is it is not connected with the electricity. Renewable energy has more capacity to provide the electricity. This electricity can be generating in remote as well as civilian area also. In this research paper we can be study the hydral energy, solar energy, wind energy, tidal energy, biotic energy as a case of renewable energy as a special case of Indian energy sector.

\section{ELECTRICITY IN INDIA:}

India is developing country; it has need of lot of electricity. As the reference of todays need, India has demand of $325 \mathrm{GW}$ electricity. India is largest electricity produce country after the China, United and States. This electricity is generated by the following sources.

With the help of these above electricity, there is per capacity electricity is the $1200 \mathrm{kwh}$. This electricity is useful for the residential, industrial, agriculture, commercial andother activity. There is shortage of this electricity, that's why renewable energy is best source for human activity and environment. Now a day there are following renewable sources for electricity.

\section{HYDRAL ENERGY:}

This kind of energy is generated by the velocity of water flow. It is one of the earlier sources for generation of electricity. In India every monsoon period, it gains the rainfall. This water is useful for the electricity. In India each state has ability to generate the hydroelectricity. India, most hydroelectricity is generated from Tehri hydropower, Konya hydroelectric project, Sardar dam. Following table gives the references in last period of Indianhydro electricity production.

\section{SOLAR ENERGY:}

This newly developed sources of electricity in India. Solar radiation has ability to develop the thermal properties. With the help of solar radiation, there is generation of the electric power is known as solar electricity or power. India is tropical country it has more capacity to generate this power. First solar plant project constructed in India at Mahabubnagar Dist. Telangana

\section{WIND ENERGY:}

Wind is horizontal movement of the air, It is kinetic energy. This kinetic energy can be converting into the mechanical energy through wind mill. It has more capacity to generate the electricity in the remote mountain area. After China - 288.32 GW, United States - 122.32 GW, Germany - 62.85 GW, India is fourth on the list of countries with the highest wind energy capacity, with all of its near $39 \mathrm{GW}$ located onshore. The country currently has no installed offshore capacity, although has outlined targets to deploy $5 \mathrm{GW}$ by 2022 and 30 GW by 2030 .

\section{TIDAL ENERGY:}

Earths $71 \%$ surface part is covered by the ocean. This ocean water is not stable it has continuous moment. This movement can be converting into kinetic energy. India's major city is located near the coastal area. This kind of renewable energy will be more applied for planning of this coastal city.

\section{GEOTHERMAL ENERGY:}

Earth's interior part is hot. Due to the interior pressure and radioactive element. There is temperature is increasing as depth is increasing. This heat is applied for the generation of electricity. This electricity can be generating anywhere of the earth surface. India has seven geothermal provinces and a numberof geothermal springs. Geothermal res ources in India have been mapped by GSI and broad estimate suggests that there could be 10 gigawatt $(\mathrm{GW})$ geothermal power potential, as per the Ministry of New and Renewable Energy (MNRE). 


\section{BIO ENERGY:}

India has a huge requirement of energy in forthcoming year. To accomplish its major requirement India has to import approximately its $73 \%$ of petroleum. In recent time government is playing an active role in promoting the adoption of renewable energy sources. Renewable energy is becoming increasingly cost competitive as compared to fossil fuel-based energy generation. The government has set a target of $175 \mathrm{GW}$ renewable power installed capacity by the end of 2022. This includes 50 GW from wind power, $100 \mathrm{GW}$ from solar, 5GW from small hydro power and 10GW from biomass power. The biomass-based energy sources for the next three year 2016-17 (500 MW), 2017-18 (750 MW) and 2018-19 (850 MW) have been set to utilize maximum potential of biomass based renewable energy (MNRE, 2016).

\section{CONCLUSION:}

India is developing nation. It has large population. For the purpose of betterment and long life, it has demand of large amount electricity. Renewable energy can be supply large amount of the electricity. In coming period coal and petroleum will be ending. This renewable energy sources has good scope. Renewable energy is suitable for the environment.

\section{REFERECNCES:}

Barbier, E. (2002). Geothermal energy technology and current status: An overview. Renewable and Sustainable Energy Reviews, 6, 3-65.10.1016/S13640321(02)00002-3

Bhatia, M., \& Banerjee, S. G. (2011). Unleashing the potential of renewable energy in India. World Bank Publications.

Central Electricity Authority (2014). Retrieved 21 .03.2015 from www.cea.nic.in:

Central Electricity Regulatory Commission (2016) http:/ / cercind.gov.in/

Deasi, Vasant (1998). Rural Development: Programme and Strategies, Vol II, Himalaya Publishing House, Bombay

Jain, H. C, (1986). Non-Conventional Source of Energy, Sterling Publishers Pvt. Ltd. New Delhi.

\begin{tabular}{|c|l|c|}
\hline No. & \multicolumn{1}{|c|}{ Sources } & Percentage (\%) \\
\hline 1 & Coal & 54 \\
\hline 2 & Large Hydroelectricity & 12 \\
\hline 3 & Small Hydroelectricity & 02 \\
\hline 4 & Solar Power & 11 \\
\hline 5 & Wind power & 10 \\
\hline 6 & Gas & 06 \\
\hline 7 & Biomass & 03 \\
\hline 8 & Nuclear & 02 \\
\hline 9 & Diesel & 01 \\
\hline
\end{tabular}

Following chart shows the generation of wind electricity in India. 
Table: Wind Energy Production in India

\begin{tabular}{|c|c|}
\hline Year & $\begin{array}{c}\text { Wind Electricity } \\
\text { production (MW). }\end{array}$ \\
\hline 2007 & 7,850 \\
\hline 2008 & 9,587 \\
\hline 2009 & 10,925 \\
\hline 2010 & 13,064 \\
\hline 2011 & 16,084 \\
\hline 2012 & 18,421 \\
\hline 2013 & 20,150 \\
\hline 2014 & 22,465 \\
\hline 2015 & 23,447 \\
\hline 2016 & 32,280 \\
\hline 2017 & 34,046 \\
\hline 2018 & 36,625 \\
\hline
\end{tabular}

Source: All India Installed Capacity of Power Station

Fig No.: 5.2 Wind power generations in India

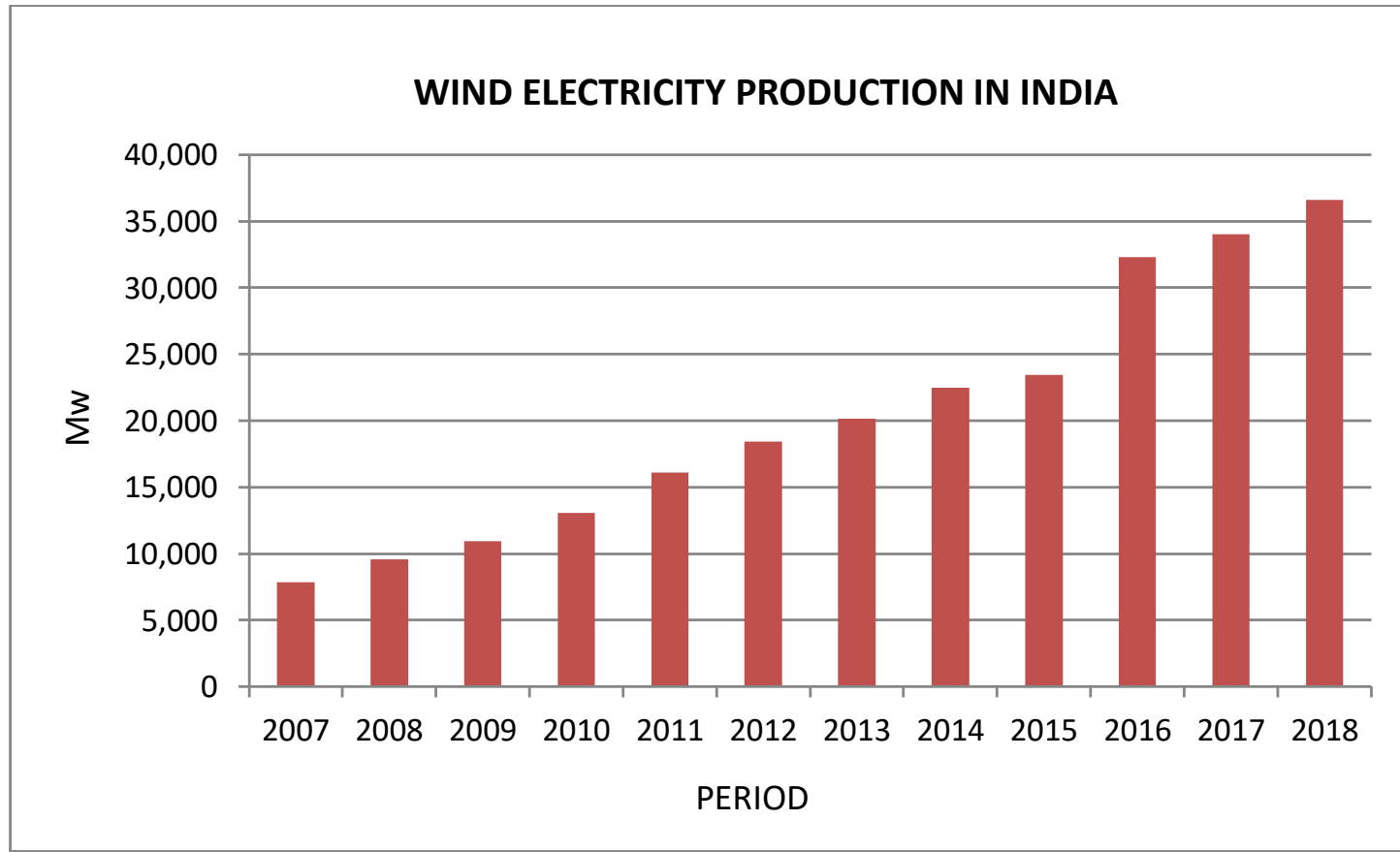

Source: Composed by Researcher 